Dr. G. Brown Goode will be published in this journal.

At this meeting the Joint Committee elected officers for the ensuing year, with the following result :

President-Gardiner G. Hubbard.

Vice-President-G. Brown Goode.

Secretary-Joseph Stanley-Brown.

Treasurer-Perry B. Pierce.

The Executive Committee elected will consist of the above and one member from each of the component societies, as follows: Anthropological, L. F. Ward; Biological, Dr. George M. Sternberg, U. S. A.; Chemical, Dr. E. A. De Schweinitz; Entomological, Wm. H. Ashmead; Geological, S. F. Emmons; National Geographic, G. K. Gilbert, and Philosophical, Prof. F. W. Clarke.

W. F. Morsell.

\section{THE PHILOSOPHICAL SOCIETY OF WASHINGTON,} JANUARY 4.

E. D. Preston read a paper on a new graphic method of reducing stars from mean to apparent places, which gave detailed exposition of a new graphical method of finding the apparent places of stars. The reduction was carried out by having the day numbers plotted on a scale sufficiently large to read two decimal places, and then multiplying these graphically by the star numbers which are calculated by construction on the same sheet. The calculation of these last quantities is facilitated in several ways. Two quadrants are drawn, and the right ascension and declination of the star to be reduced being selected, the simple trigonometrical functions are immediately read off from the figure.

For those terms where a product of functions appears, the method enables the operator to construct the quantity by different processes. That one is chosen which arrives at a resulting line lying at right angles to the day numbers already plotted. This makes their multiplication a very easy matter. In actual practice the construction lines shown on the diagram are of course not drawn. The whole sheet being divided into small squares, the computer is able to project the point visually, and to determine the intersections of the necessary constructions without actually drawing them.
The method has been principally used for checking the regular computation, and this can be done in less than one-half the time required to make the first reduction. But with a scale sufficiently enlarged there seems to be no reason why the system should not be used with entire success for a complete and separate solution.

January 18 th the following papers were read : Dr. G. Brown Goode, on 'The Principles of Museum Administration;' Mr. Isaac Winston, on the 'Present form of precise levelling apparatus in use by the U. S. Coast and Geodetic Survey;' Mr. G. R. Putnam, on the 'Results. of Recent Pendulum Observations.'

$$
\begin{aligned}
& \text { BERNARP R. GREEN, } \\
& \text { Secretary. }
\end{aligned}
$$

CHEMICAL SOCIETY OF WASHINGTON, 83D REGULAR MEETING, THURSDAY, NOVEMBER 14, 1895.

The President, Chas. E. Munroe, in the chair, with thirty-five members present. The following were elected to membership: H. B. Hodges, Allan Wade Dow, W. W. Skinner and F. B. Bomberger. Dr. Marcus Benjamin read a paper on 'The Smithsonian Institution's Contributions to Chemistry from 1846 to 1896.' He referred to the fact that Smithson in his time was considered as among the most expert of chemists in elegant analysis. This he thought had much to do with the provision made for a chemical laboratory in the original 'programme of organization of the Smithsonian Institution.' He traced the history of the laboratory, mentioning the chemists who have occupied it, among whom was J. Laurence Smith. The chemical publications of the Institution were reviewed, beginning with that of Dr. Robert Hare 'On the Explosiveness of Nitre,' in 1850, down to that 'On the Density of Oxygen and Hydrogen, and on the Reduction of their Atomic Weights,' by Edward N. Morley, in 1895. The lectures by Cooke, Johnson, Hunt and others were mentioned and the grants of funds to Genth, Gibbs and Morley for chemical research were described.

The work of Booth as shown in his 'Report of Recent Instruments in the Chemical Arts;' of Clarke in his 'Constants of Nature,' and of Bolton in his 'Bibliography of Chemistry,' as 
well as the many indexes to chemical literature by Magee, Bolton, Traphagen, Tuckerman and others were mentioned and discussed. The paper was concluded with a full bibliography of the chemical papers published by the Smithsonian Institution.

Mr. Cabell Whitehead read some 'Notes on a recent visit to European Mints.' In the discussion of this paper mention was made of the explosions that occur commonly in lighting a 'Buffalo Dental Company's' muffler furnace, and Mr. Dewey said they could be avoided by raising the whole body of the furnace by a simple arrangement of movable levers and then slipping a lighted paper over the burners.

Under the title 'Calcium Phosphide,' Prof. Chas. E. Munroe described the process of manufacture which he invented and carried into operation at the United States Naval Torpedo Station in 1891. The novelty consisted in the use of the iron crucibles, in which quicklime was heated to redness, after which sticks of white phosphorus were added through an iron tube which penetrated the cover. The process was so simple that eventually it was carried on by unskilled laborers, and the phosphide which was then selling in the market for $\$ 2.25$ per $\mathbf{l b}$. was produced at a cost of 20 cents per $1 \mathrm{lb}$. It was manufactured for use in Automobile torpedoes while at practice, and was found so efficient that when a pound in its container was submerged in 18 feet of water it gave a flame 2 feet in height on the surface, which continued to burn for three hours.

\section{A. C. Peale, Secretary.}

BOSTON SOCIETY OF NATURAL HISTORY.

The Society met December 18 ; one hundred and six persons present.

Mr. F. W. Crosby described a remarkable locality in Cephalonia where the water runs from the sea into the land at a rate varying from 4,000 to 10,000 cubic feet per minute. This immense quantity of water is utilized as power for mills, but what becomes of it is not known.

Prof. G. Frederick Wright discussed the present status of Glacial man in America. $\mathrm{He}$ showed an ancient chipped knife found by Mr.
Huston at Brilliant, Ohio, and gave additional evidence, the result of a renewed study. upon the ground, to prove that the implement was not intrusive but was found in the undisturbed strata of the original terrace. Prof. Wright's paper was illustrated by a series of lantern slides.

Prof. H. W. Haynes reviewed the evidence of early man in America as presented by Mr. Upham and Miss Babbitt, and showed some of the rudely flaked quartzes found by Miss Babbitt, at Little Falls, Minn.

$$
\begin{aligned}
& \text { Samuel Henshaw, } \\
& \text { Secretary. }
\end{aligned}
$$

GEOLOGICAL CONFERENCE OF HARVARD UNIVERSITY, JANUARY 7, 1896.

Some occurrences of Eruptive Granite in the Archean Highlands of New Jersey: By J. E. WOLFF.

Occurrences of eruptive granite have been described in the white limestone area from Franklin northeastward, to which the present crystalline condition of the limestone is ascribed as due to contact metamorphism. These occurrences lie in the valley at the west base of the Highlands. The object of this commurication was to describe the occurrence of a large area of granite within the area of the gneisses themselves, lying near the west edge of the plateau formed by the Archean gneisses and nearly due east of Franklin. The area so far as determined is about six miles from north to south and two miles wide; the field evidence seems to prove its eruptive character through the bounding gneisses.

JANUARY 14, 1896.

1. National Concentration of Ore Deposits: By A. C. LANE. (To be published in the Engineering and Mining Journal.)

2. Plains of Marine and Subaërial Denudation: By W. M. Davis. (To be published in Bulletin of the Geological Society of America.)

T. A. JAGGAR, JR., Recording Secretary.

TORREY BOTANICAL CLUB.

THE annual meeting of the Torrey Botanical Club was held on Tuesday evening, January 